\title{
Spray Pyrolysis Synthesis of Pure and Mg-Doped Manganese Oxide Thin Films
}

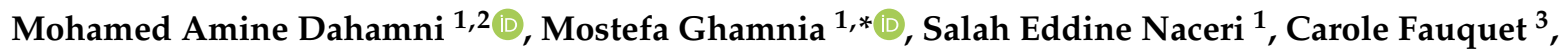 \\ Didier Tonneau ${ }^{3}$, Jean-Jacques Pireaux ${ }^{4}\left[\right.$ and Abed Bouadi ${ }^{2}$
}

1 Laboratoire des Science de la Matière Condensée (LSMC), Université Oran 1 Ahmed Ben Bella, Oran 31100, Algeria; dahamnimohamedelamine@gmail.com (M.A.D.); salahna77@gmail.com (S.E.N.)

2 Department de Physique, Université de Relizane, Relizane 48000, Algeria; abed.bouadi@cu-relizane.dz

3 Centre Interdisciplinaire de Nanoscience de Marseille (CINaM), Université d'Aix Marseille, 13009 Marseille, France; fauquet@cinam.univ-mrs.fr (C.F.); tonneau@cinam.univ-mrs.fr (D.T.)

4 LISE Laboratory (NISM-LISE), Namur Institute of Structured Matter, Université de Namur, 5000 Namur, Belgium; jean-jacques.pireaux@unamur.be

* Correspondence: mghamnia@yahoo.fr

Citation: Dahamni, M.A.; Ghamnia, M.; Naceri, S.E.; Fauquet, C.; Tonneau, D.; Pireaux, J.-J.; Bouadi, A. Spray Pyrolysis Synthesis of Pure and Mg-Doped Manganese Oxide Thin Films. Coatings 2021, 11, 598. https:// doi.org/10.3390/coatings11050598

Academic Editor: Irina Ya Mittova

Received: 9 April 2021

Accepted: 17 May 2021

Published: 19 May 2021

Publisher's Note: MDPI stays neutral with regard to jurisdictional claims in published maps and institutional affiliations.

Copyright: (c) 2021 by the authors. Licensee MDPI, Basel, Switzerland. This article is an open access article distributed under the terms and conditions of the Creative Commons Attribution (CC BY) license (https:// creativecommons.org/licenses/by/ $4.0 /)$.

\begin{abstract}
Pure and Mg-doped manganese oxide thin films were synthesized on heated glass substrates using the spray pyrolysis technique. The surface chemical composition was investigated by the use of X-ray photoelectron spectroscopy (XPS). Structural and morphological properties were studied by using X-ray diffraction (XRD), scanning electron microscope (SEM) and atomic force microscopy (AFM). Optical properties were characterized by UV-visible spectroscopy. XPS spectra showed typical Mn (2p3/2), (2p1/2) and $\mathrm{O}(1 \mathrm{~s})$ peaks of $\mathrm{Mn}_{3} \mathrm{O}_{4}$ with a slight shift attributed to the formation of different chemical states of manganese. XRD analysis revealed the tetragonal phase of $\mathrm{Mn}_{3} \mathrm{O}_{4}$ with a preferred (211) growth orientation that improved with $\mathrm{Mg}$-doping; likewise, grain size is observed to increase with the $\mathrm{Mg}$ doping. SEM images of $\mathrm{Mn}_{3} \mathrm{O}_{4}$ films showed rough surfaces composed of uniformly distributed nanograins whose size decreases with the Mg-doping. The manganese oxide films surface observed in AFM show a textured, rough and porous surface. The combination of transmittance and absorption data in the UV-visible range allowed determining the energy values of the Eg band gap (1.5-2.5 eV). The decrease of the band gap with the Mg-doping increase is attributed to the influence of the greater size of the $\mathrm{Mg}^{2+}$ ion in the manganese oxide lattice.
\end{abstract}

Keywords: MnO; XPS; AFM; nanograins; spray pyrolysis

\section{Introduction}

Oxides in nanometric films have received increasing interest to the potential applications that derive from their interesting electrical, magnetic and catalytic properties. Manganese oxides in nanometric films are intriguing compounds possessing excellent electrochemical activity allowing it to be used in electrochemistry applications. Due to the three $\mathrm{Mn}^{2+}, \mathrm{Mn}^{3+}$ and $\mathrm{Mn}^{4+}$ different oxidative states of manganese, the manganese oxide compound exists in four structures $\left(\mathrm{MnO}, \mathrm{Mn}_{2} \mathrm{O}_{3}, \mathrm{MnO}_{2}\right.$ and $\left.\mathrm{Mn}_{3} \mathrm{O}_{4}\right)$ [1], which all present interesting physical and chemical properties as important as those of the metal oxides materials $\left(\mathrm{ZnO}, \mathrm{SnO}_{2}, \mathrm{NiO}, \mathrm{CuO}, \ldots\right)$ belonging to the transparent conducting oxides (TCO) family. Manganese oxide thin films are well suited for various applications such as in optoelectronic applications for their use in solar energy conversion [2,3], electrochemical capacitors [4,5], batteries, sensors [6], chemical sensors [7,8], magnetoelectronic devices, electrochemical energy storage devices and catalytic activity [9-11]. Quality manganese oxide thin films are relatively easy to prepare, with many physical and chemical techniques such as atomic layer deposition [12], co-precipitation [13], sputtering [14], Molecular Beam Epitaxy [15], chemical vapor deposition [16] and spray pyrolysis [17,18]. It has been shown earlier $[19,20]$ that, amongst these techniques, spray pyrolysis presents many advantages: 
it is cheaper and easier to implement, while allowing for obtainment of homogeneous coatings on large areas. Furthermore, it is easy to obtain metals-doped films by simply adding some other solution(s) to the primary one. In this work, we synthesize and characterize pure and $\mathrm{Mg}$-doped manganese oxide thin films using spray pyrolysis but in order to obtain oxide thin films of good quality, it is necessary to control efficiency the phase formation, the grain size, the shape and morphologies of nanometric films. It is well known that these parameters have great influence on the physical properties and applications of oxides in nanometric films. This paper allowed us to review the synthesis of manganese oxides films with various $\mathrm{Mg}$-doping for photocatalytical properties study which will be applied in industrial waste from textile factories.

\section{Materials and Methods}

Pure and doped manganese oxide thin films were deposited onto heated glass substrates using the spray pyrolysis technique. The primary solution permitting to obtain pure manganese oxide was prepared with $0.1 \mathrm{M}$ manganese chloride $\left(\mathrm{MnCl}_{2}, 6 \mathrm{H}_{2} \mathrm{O}\right)$ in $100 \mathrm{~mL}$ deionized water. A secondary solution prepared from magnesium chloride hexahydrate $\left(\mathrm{MgCl}_{2}, 6 \mathrm{H}_{2} \mathrm{O}\right)$ was added for the $\mathrm{Mg}$-doping to the primary solution at various concentrations $((\mathrm{Mg} / \mathrm{Mn})$ ratio: $3 \%, 5 \%, 7 \%$ and $9 \%)$. These solutions were sprayed onto heated glass substrates maintained at $350{ }^{\circ} \mathrm{C}$ during the deposit time. Figure 1 schematically illustrates the principle of the pyrolysis method used in this study.

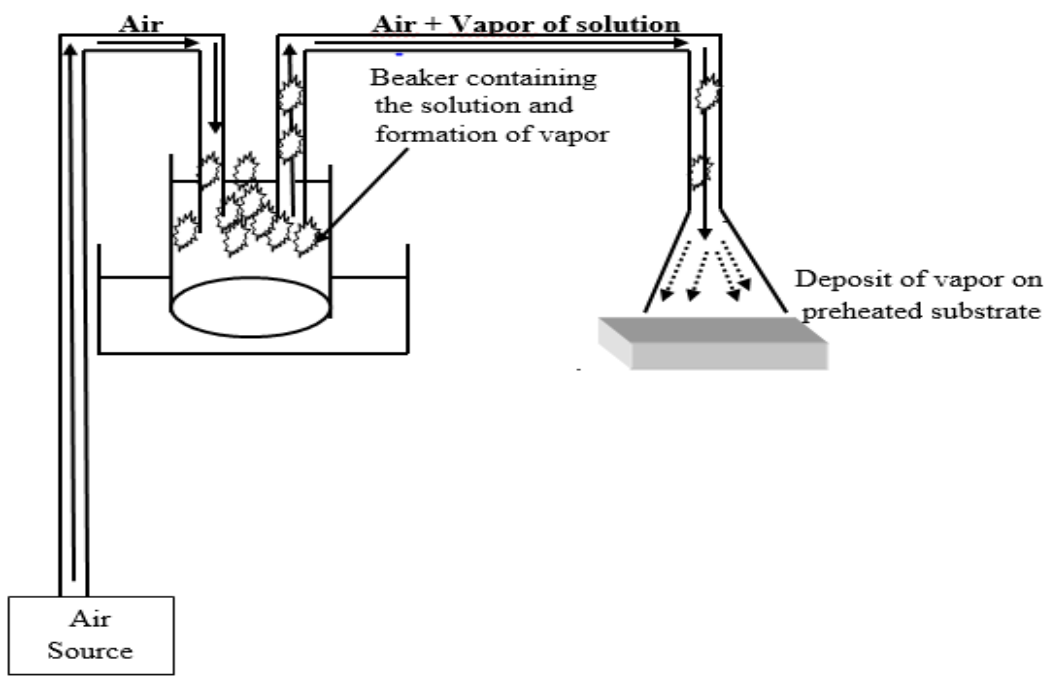

Figure 1. Schematic diagram of the used spray pyrolysis technique.

The obtained pure and Mg-doped samples were characterized by techniques adapted to thin films analysis. X-ray photoelectron spectroscopy (XPS-K-alpha apparatus from Thermo Scientific Instruments, Waltham, MA, USA) and X-ray diffraction (XRD-X'Pert PRO from PANalytical (Malvern, UK) utilizing copper line of wavelength $\lambda=1.54 \AA$ ) were used for chemical compositional analysis, and structural study, respectively. Microstructural and morphological characterizations were obtained by scanning electron microscopy (SEM JEOL 7500-F Instrument, Tokyo, Japan) and atomic force microscopy (AFM-Dimension Edge from Bruker, Bruker, MA, USA), respectively. The materials band gap energy (Eg) is calculated using the Tauc's plot, combining absorption and transmittance data extracted from UV-visible (Specord 50 plus spectrophotometer, Analytik Jena, Jena, Germany) analysis.

\section{Results}

\subsection{XPS Compositional Analysis}

XPS survey spectra are used to investigate the chemical composition and the valence states of manganese and oxygen for the pure and Mg-doped manganese oxide films 
(Figure 2). Carbon is the sole contaminant with some traces of nickel detected on the films' surface; the other peaks that appear in the spectra are attributed to the core levels of the $\mathrm{O}$ and $\mathrm{Mn}$ elements; traces of the magnesium dopant were detected from their $\mathrm{Mg}$ (1s) core level. The principal Mn (2p3/2), (2p1/2) and O (1s) core levels are shown in Figure 3. Binding energy shifts of the Mn (2p) and $\mathrm{O}(1 \mathrm{~s})$ peaks are listed in Table 1; they present an average half-eV oscillation, probably due to the formation of different chemical states of the $\mathrm{Mn}$ and resulting into the formation of mixed oxides $\left(\mathrm{MnO}, \mathrm{Mn}_{3} \mathrm{O}_{4}\right)$. Indeed, as reported by Li et al. [21], the $\mathrm{Mn}(2 \mathrm{p} 3 / 2)$ peak that appears around $640.0 \mathrm{eV}$ is attributed to $\mathrm{Mn}^{2+}$ cations, whereas peaks detected in the energy range $641.0-642.0 \mathrm{eV}$ are assigned to $\mathrm{Mn}^{3+}$ and $\mathrm{Mn}^{4+}$, respectively. In the present work, the binding energies are recorded at $640.4 \mathrm{eV}$ for the pure films and vary from 641.0 to $641.5 \mathrm{eV}$ for the Mg-doped films. This is consistent with the pure films corresponding to the growth of the $\mathrm{MnO}$ compound, while the $\mathrm{Mg}$-doped films show the formation of $\mathrm{Mn}_{3} \mathrm{O}_{4}$.

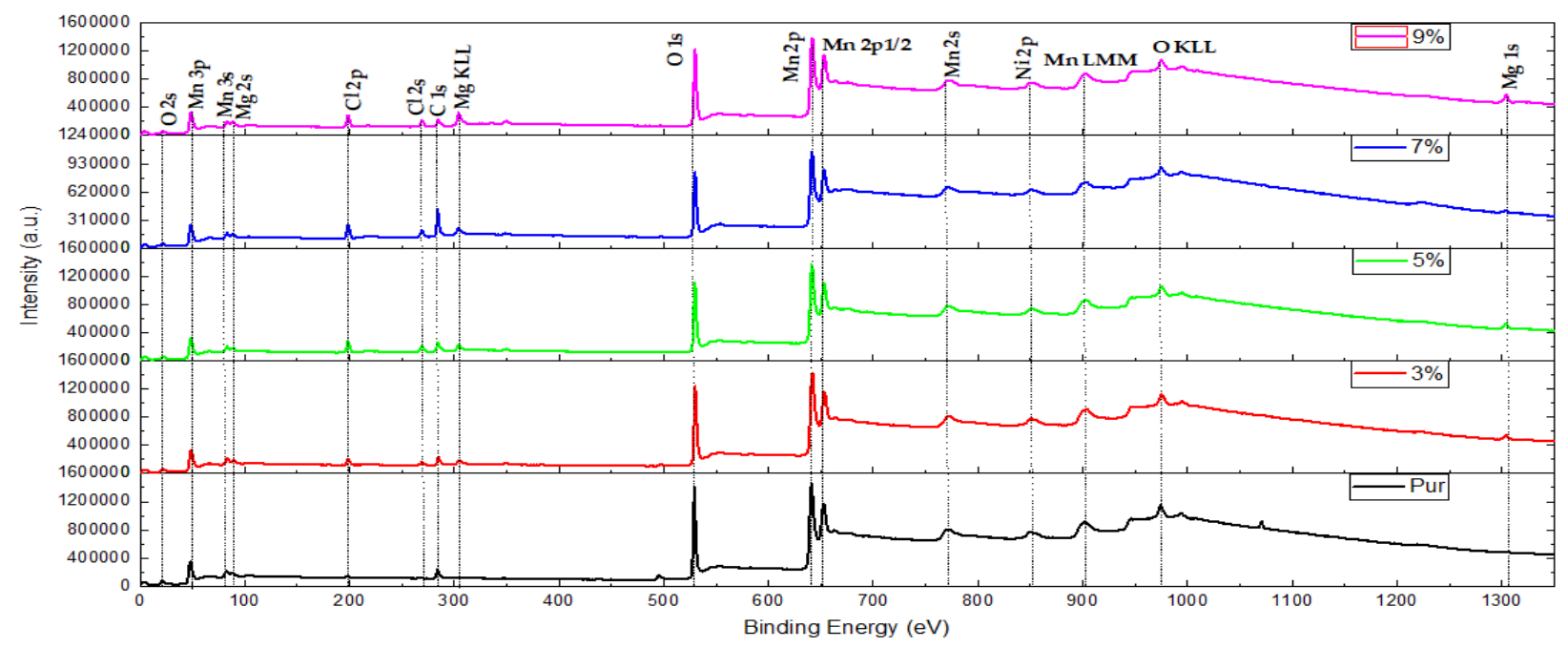

Figure 2. XPS survey spectra of the pure and Mg-doped manganese oxide thin films.

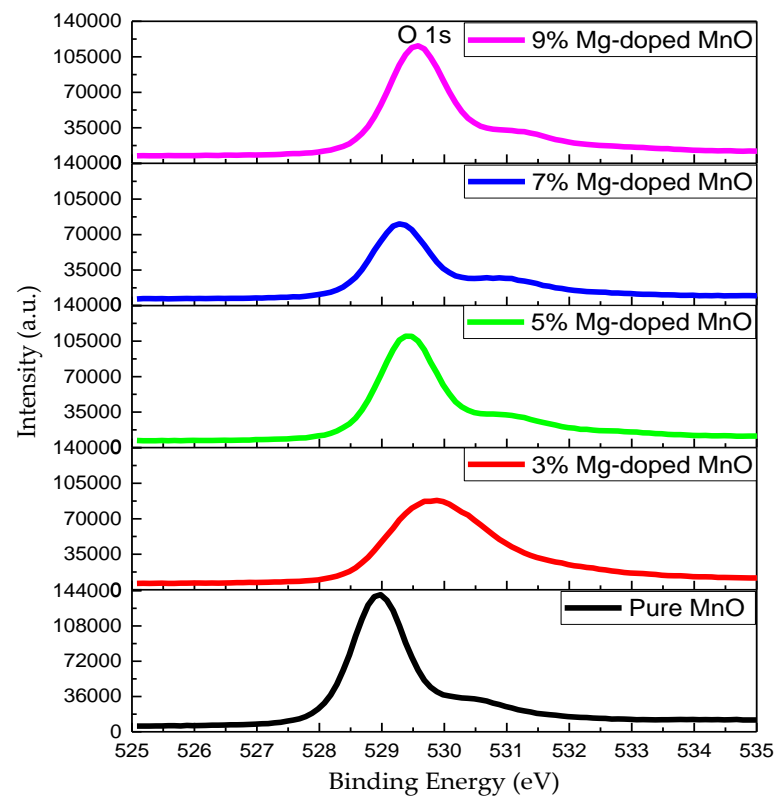

(a)

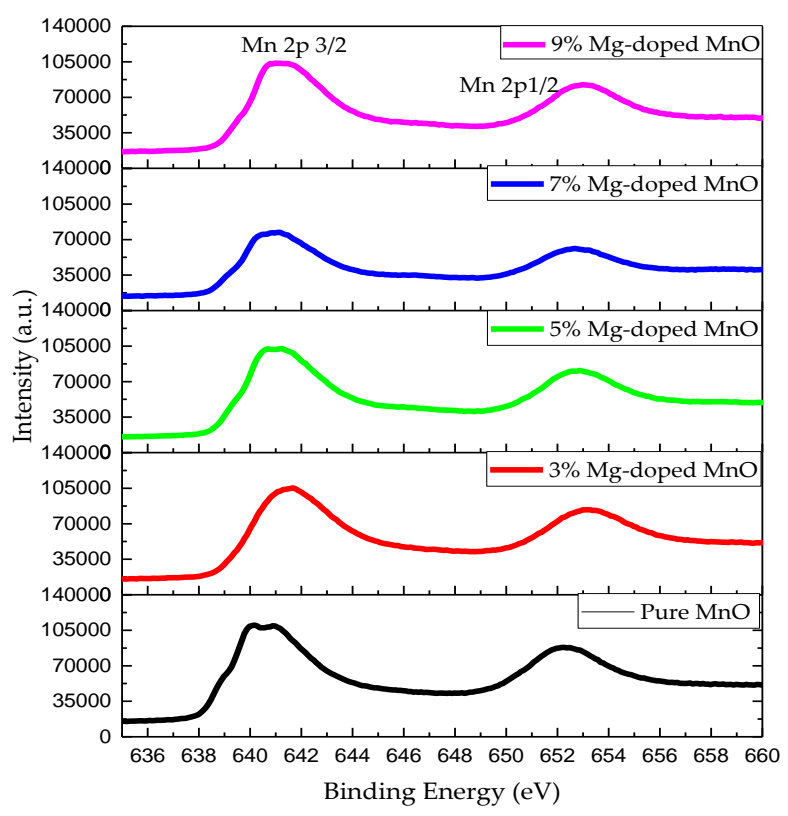

(b)

Figure 3. XPS spectra of the most intense core levels peaks of manganese (b) Mn (2p) and oxygen (a) O (1s). 
Table 1. XPS determined binding energies of the most intense $\mathrm{O}$ and Mn elemental peaks.

\begin{tabular}{cccc}
\hline Samples & O (1s) Binding Energy (eV) & $\begin{array}{c}\text { Mn (2p3/2) Binding Energy } \\
\text { (eV) }\end{array}$ & $\begin{array}{c}\text { Mn (2p1/2) Binding Energy } \\
\text { (eV) }\end{array}$ \\
\hline Pure MnO film & 529 & 640.4 & 652.4 \\
3\% Mg-doped film & 529.9 & 641.5 & 653.5 \\
5-7\% Mg-doped film & 529.5 & 641.0 & 653.0 \\
9\% Mg-doped film & 529.7 & 641.5 & 653.6 \\
\hline
\end{tabular}

The oxygen peak is decomposed into two distinct components (Figure 3a): the first one appears at $529 \mathrm{eV}$ and is due to $\mathrm{Mn}-\mathrm{O}$ bonds. The other less intense oxygen peak positioned at $530.6 \mathrm{eV}$ is related to contaminant molecules loosely bound the surface. The curve-fitted XPS spectra (Figure 4) of the Mn (2p) core levels suggest in fact that the $2 \mathrm{p} 3 / 2$ peak is composed of a doublet, with one component at $639.5 \mathrm{eV}$ and the other one at $641.5 \mathrm{eV}$. This confirms the presence of two different valences, $\mathrm{Mn}^{2+}$ and $\mathrm{Mn}^{3+}$, highlighting the growth of two $\mathrm{MnO}$ and $\mathrm{Mn}_{3} \mathrm{O}_{4}$ compounds. A larger and less intense component appears at $644.4 \mathrm{eV}$; it is due to the presence of the $\mathrm{Mn}^{4+}$ state of manganese.
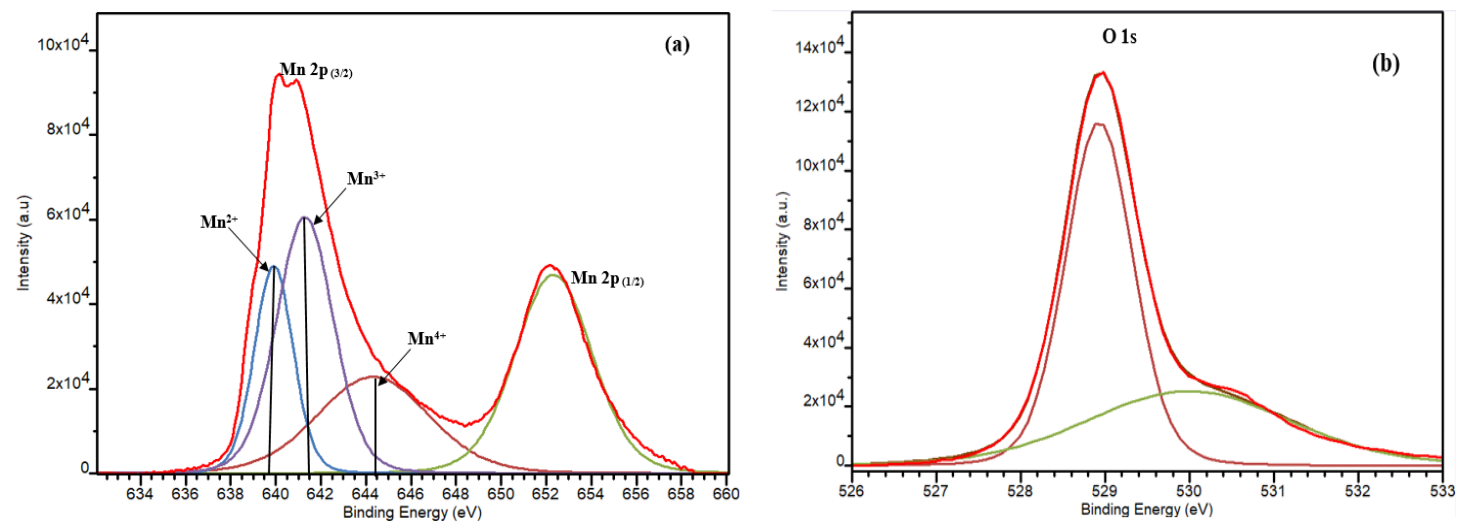

Figure 4. Curve-fitted XPS spectra: (a) Mn (2p3/2) and Mn (2p1/2) peaks (b) O (1s) core level.

The transitions of XPS spectra of MnO compound are strongly dependent on the valence of the manganese $\left(\mathrm{Mn}^{2+}, \mathrm{Mn}^{3+}, \mathrm{Mn}^{4+}\right)$. They are discussed and reported by Ilton $[22,23]$ and Cerato [24,25].

\subsection{XRD Characterization}

Figure 5 shows the XRD patterns of the deposited pure and Mg-doped thin films. Fourteen peaks of different intensities are resolved with the principal (112), (103) and (211) indexed planes, corresponding to $2 \theta$ diffraction angles around $28^{\circ}, 32.5^{\circ}$ and $36.5^{\circ}$. These peaks are the mostly shown and discussed in [26-28], and, with reference to the JCPDS cards No. 80-0382 and 00-024-0734, they do confirm the presence of the tetragonal $\mathrm{Mn}_{3} \mathrm{O}_{4}$ phase. The intensity of the indexed plane (211) increases with the increase of $\mathrm{Mg}$ doping and is particularly pronounced for $7 \%$ and $9 \%$ doping. It results also in diffraction peak shift. This indicates that the films grow preferentially along the (211) direction and confirms the crystallization improvement of the films under the Mg-doping effect. Figure $4 \mathrm{~b}$ shows increased diffraction peak at around $43^{\circ}$, which does not appear on the other spectra; it is probably due to a faulty placement of the sample. On the other hand, the position of this peak is unstable and shifts to the left and to the right, as observed on XPS spectra (Table 1, Figure 6). These oscillations are attributed to the presence of two $\left(\mathrm{Mn}^{2+}, \mathrm{Mn}^{3+}\right)$ valence types confirming the formation of a mixed oxide $\left(\mathrm{MnO} / \mathrm{Mn}_{3} \mathrm{O}_{4}\right)$. Similar behaviors were observed on the XRD spectra of $\mathrm{Sr}$ doped-ZnO [29] and were attributed to a size effect between $\mathrm{Zn}^{2+}$ and $\mathrm{Sr}^{2+}$ ions. If we compare the ionic radii of the $\mathrm{Mn}^{2+}(1.17 \AA), \mathrm{Mn}^{3+}(0.66 \AA)$ and $\mathrm{Mn}^{4+}(0.60 \AA)$ ions and of $\mathrm{Mg}^{2+}(0.66)$, it is only the $\mathrm{Mn}^{2+}$ ion that can explain the shift of 
the XPS and DRX peaks. The void resulting from the ratio $\mathrm{r}_{\mathrm{Mn}^{2+}} / \mathrm{r}_{\mathrm{Mg}^{2+}}=1.77$ is expected to destabilize the crystallographic structure of the Mn-O film, which would cause the observed perturbations of the peak intensities (positions) in the XRD (and XPS) measurements.

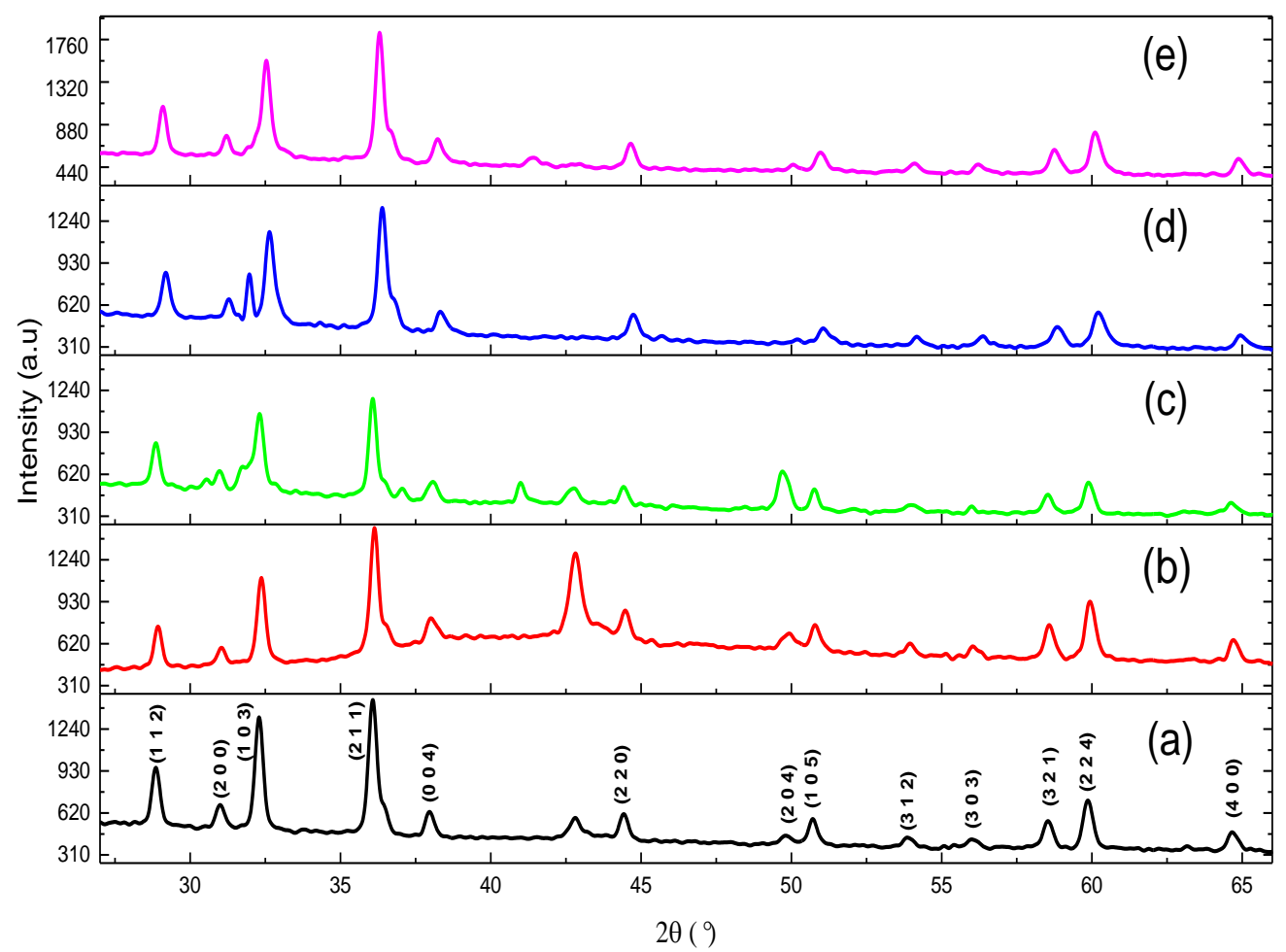

Figure 5. X-ray diffraction patterns of pure and $\mathrm{Mg}$-doped $\mathrm{Mn}-\mathrm{O}$ thin films. (a): Pure $\mathrm{MnO}$; (b): 3\% Mg-doped MnO; (c): 5\% Mg-doped MnO; (d): 7\% Mg-doped MnO; (e): 9\% Mg-doped MnO.

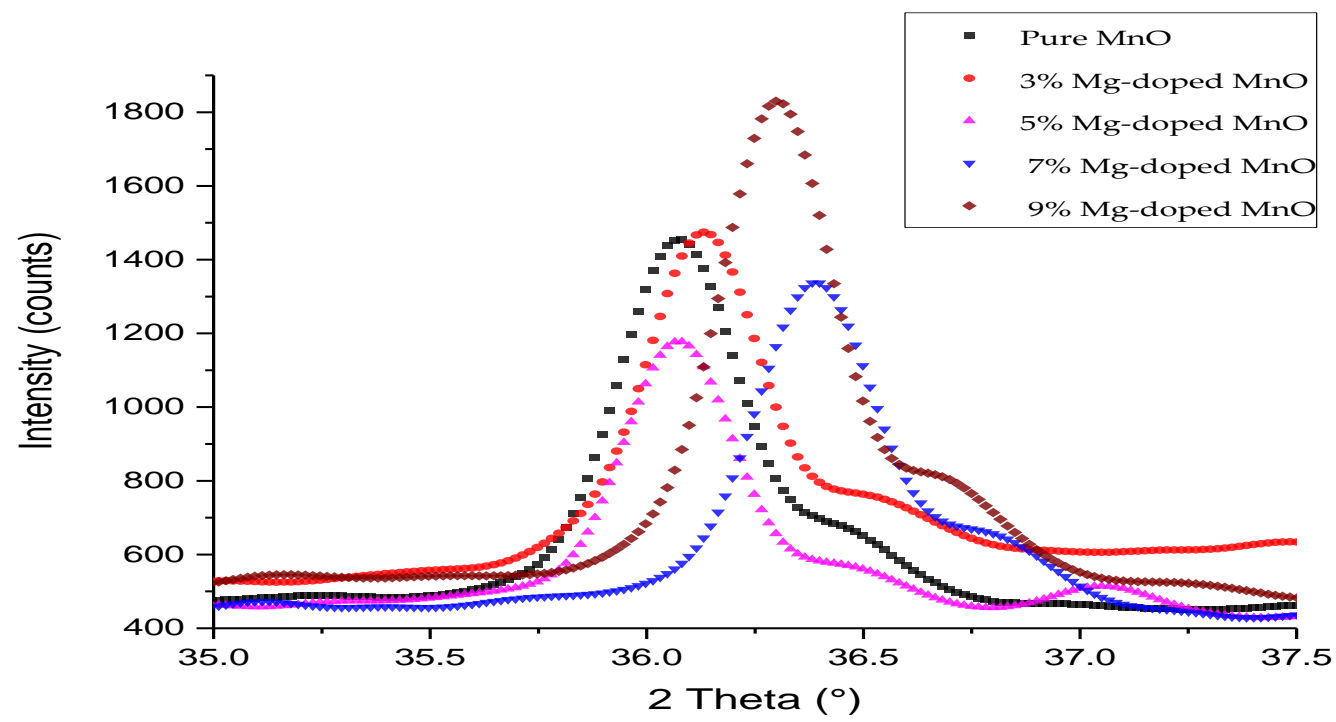

Figure 6. Shift of the position of (211) diffraction peak as measured of the five different deposited films.

The $a, b$ and $c$ tetragonal lattice parameters were determined from the XRD spectra. The tetragonal structure is defined by $a=b \neq c$ and the interplanar spacing $d$ is a function 
that is dependent on $a, b$ and $c$ and on the indexed diffraction peaks $(h k l)$ as shown in the following relation:

$$
\frac{1}{d^{2}}=\frac{\left(h^{2}+k^{2}\right)}{a^{2}}+\frac{l^{2}}{c^{2}}
$$

The interplanar spacing $d$ can also be determined from Bragg's law below:

$$
2 d \sin \theta=n \lambda,
$$

where $d$ is the interplanar spacing, $\theta$ is the Bragg diffraction angle, $n$ is the order of diffraction (usually $n=1$ ) and $\lambda$ is the $X$-ray wavelength.

By combining Equations (1) and (2) and applying them to the (211) and (103) most intense peaks, one easily calculates the $a$ and $c$ lattice parameters that are listed in the following Table 2.

\begin{tabular}{|c|c|c|c|c|c|c|c|}
\hline Sample & $2 \theta\left({ }^{\circ}\right)$ & $(h k l)$ & $d(\AA)$ & $\begin{array}{c}a=b \\
(\AA)\end{array}$ & $c(\AA)$ & $a=b(\AA)$ in Literature & $c(\AA)$ in Literature \\
\hline \multirow{2}{*}{ Pure $\mathrm{MnO}$} & 32.29 & 103 & 2.770 & \multirow{2}{*}{5.7643} & \multirow{2}{*}{9.4757} & $8.135[30]$ & $9.28[30]$ \\
\hline & 36.08 & 211 & 2.488 & & & $5.752[31]$ & $9.47[31]$ \\
\hline \multirow{2}{*}{$\mathrm{MnO}(3 \% \mathrm{Mg})$} & 32.36 & 103 & 2.763 & \multirow{2}{*}{5.7565} & \multirow{2}{*}{9.4517} & & \\
\hline & 36.13 & 211 & 2.484 & & & & \\
\hline \multirow{2}{*}{$\mathrm{MnO}(5 \% \mathrm{Mg})$} & 32.29 & 103 & 2.770 & \multirow{2}{*}{5.7647} & \multirow{2}{*}{9.4766} & & \\
\hline & 36.07 & 211 & 2.487 & & & & \\
\hline \multirow{2}{*}{$\mathrm{MnO}(7 \% \mathrm{Mg})$} & 32.65 & 103 & 2.740 & \multirow{2}{*}{5.7166} & \multirow{2}{*}{9.3677} & & \\
\hline & 36.39 & 211 & 2.466 & & & & \\
\hline \multirow{2}{*}{$\mathrm{MnO}(9 \% \mathrm{Mg})$} & 32.53 & 103 & 2.751 & \multirow{2}{*}{5.7302} & \multirow{2}{*}{9.4041} & & \\
\hline & 36.31 & 211 & 2.472 & & & & \\
\hline
\end{tabular}

Table 2. Determination of the $a$ and $c$ lattice parameters for the five different deposited films.

By using the Debye-Scherrer Equation (3) that is extensively used with more details by Borchert et al. [32], the average Mn-O crystallite size may be estimated according to:

$$
D=\frac{0.9 \lambda}{\beta(2 \theta) \cos \theta}
$$

where $\lambda$ is the $X$-ray wavelength, $\theta$ is the Bragg diffraction angle and $\beta$ is the broadening of the diffraction peak measured at half of its maximum intensity.

The defects density in the synthesized Mn-O films defined as the length of dislocation lines per unit volume of the crystal can be estimated by the use of the following Equation (4):

$$
\delta=\frac{1}{D^{2}}
$$

where $D$ is the average $\mathrm{Mn}-\mathrm{O}$ crystallite size determined from Equation (3).

By application of Equations (3) and (4) to the intense diffraction peak (211) for the pure and $\mathrm{Mg}$-doped $\mathrm{Mn}-\mathrm{O}$, the determined values of $D$ and $\delta$ are shown in Table 3.

Table 3. Determination of the average crystallite size $D$ and defects density $\delta$ for the five different thin films.

\begin{tabular}{ccccccc}
\hline Sample & $\mathbf{2 \theta}\left({ }^{\circ}\right)$ & $\boldsymbol{\theta}\left(^{\circ}\right)$ & $\boldsymbol{d}_{(\mathbf{2 1 1})}(\AA)$ & $\left.\boldsymbol{\beta} \mathbf{(}^{\circ}\right)$ & $\boldsymbol{D}(\mathbf{n m})$ & $\boldsymbol{\delta}(\mathbf{1 0}-\mathbf{3})$ \\
\hline Pure MnO & 36.08 & 18.04 & 2.488 & 0.3354 & 24.9075 & 1.6119 \\
$\mathrm{MnO}(3 \% \mathrm{Mg})$ & 36.13 & 18.06 & 2.484 & 0.3088 & 27.0534 & 1.3663 \\
$\mathrm{MnO}(5 \% \mathrm{Mg})$ & 36.07 & 18.03 & 2.487 & 0.2844 & 29.3722 & 1.1591 \\
$\mathrm{MnO}(7 \% \mathrm{Mg})$ & 36.39 & 18.19 & 2.466 & 0.3624 & 23.0756 & 1.8779 \\
$\mathrm{MnO}(9 \% \mathrm{Mg})$ & 36.31 & 18.15 & 2.472 & 0.3095 & 27.0081 & 1.3709 \\
\hline
\end{tabular}




\subsection{SEM and AFM Analysis}

The morphologies of the different $\mathrm{Mn}-\mathrm{O}$ films recorded by SEM are shown in Figure 7 (magnification $\times 40,000$ ). Morphological changes in $\mathrm{MnO}$ are clearly linked to variations in the Mg-doping from 3\% to 9\%: the Mg-doping appears to have an effect on the surface roughness with the pure $\mathrm{MnO}$ surface composed of larger grains, appearing rougher than other Mg-doped surfaces.

Pure Mn-O

3\% Mg-Doped
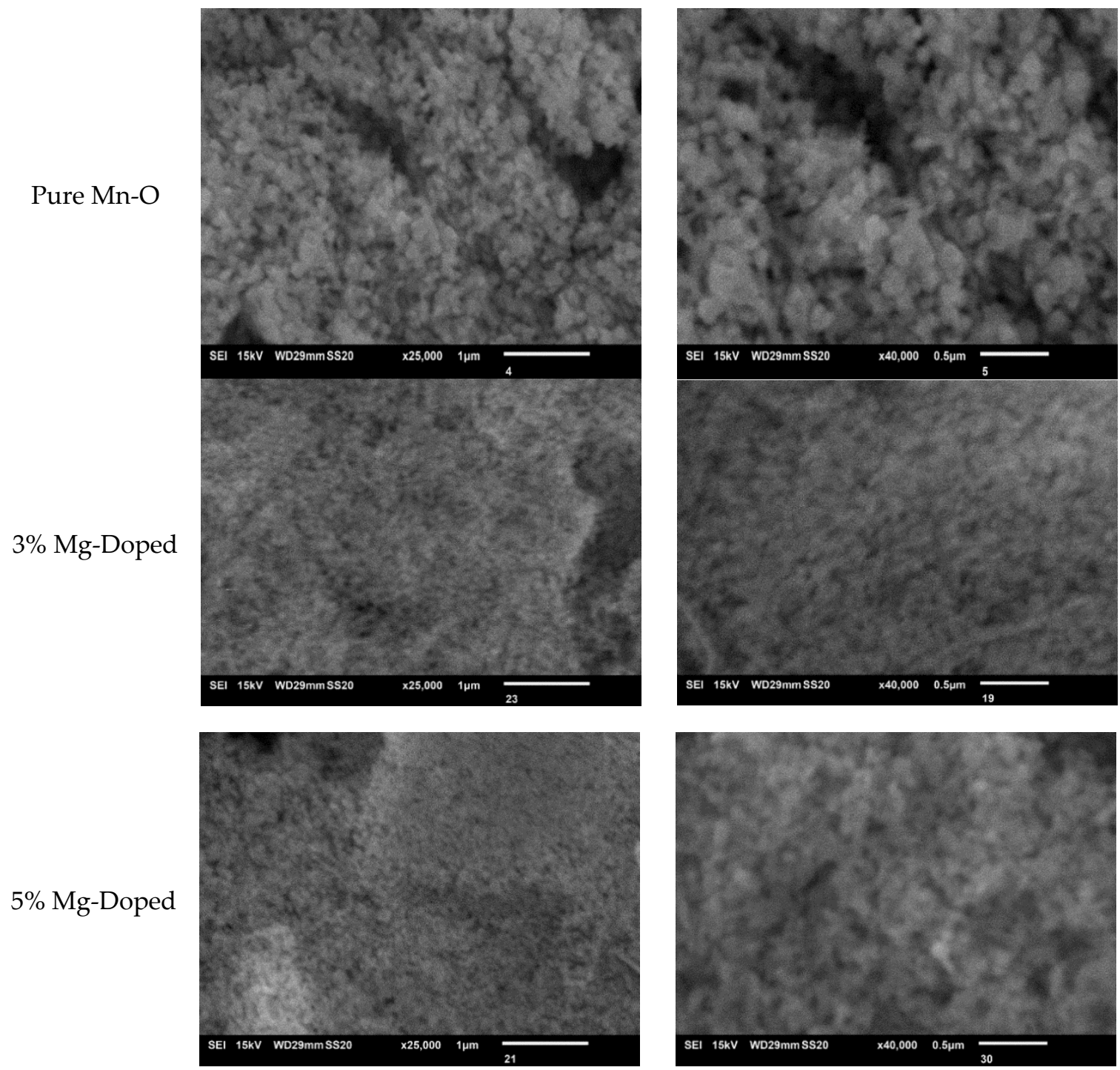

Figure 7. SEM images of pure and Mg-doped Mn-O oxide recorded at a magnification $\times 40,000$ (1 and 0.5 scales are shown).

The Mg-doping effect on the topography of the films' surfaces is confirmed by Atomic Force Microscope (AFM) (Figure 8) using the tapping mode in $2 \mu \mathrm{m} \times 2 \mu \mathrm{m}$ areas. It is observed that the $\mathrm{MnO}$ deposit is not homogeneous but formed by grains aggregated in "egg" shaped forms. The black areas represent the glass substrate showing the formation of $\mathrm{MnO}$ porous nanoflakes. As shown by the profiles taken on a horizontal line on each image, the aggregation of the grains increases with the increase of the Mg-doping. The calculated average rms roughness on this line is $50 \mathrm{~nm}$ for the pure $\mathrm{MnO}, 80 \mathrm{~nm}$ for $3 \% \mathrm{Mg}$ doped-MnO and $130 \mathrm{~nm}$ for the $5 \%-7 \% \mathrm{Mg}$ doped-MnO. 


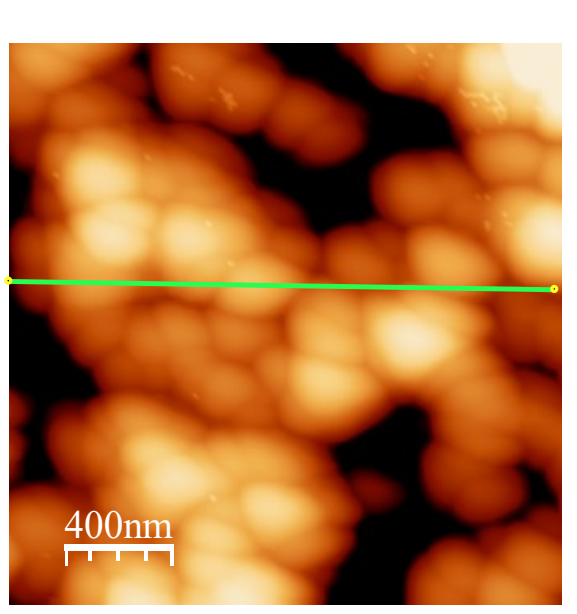

(a)

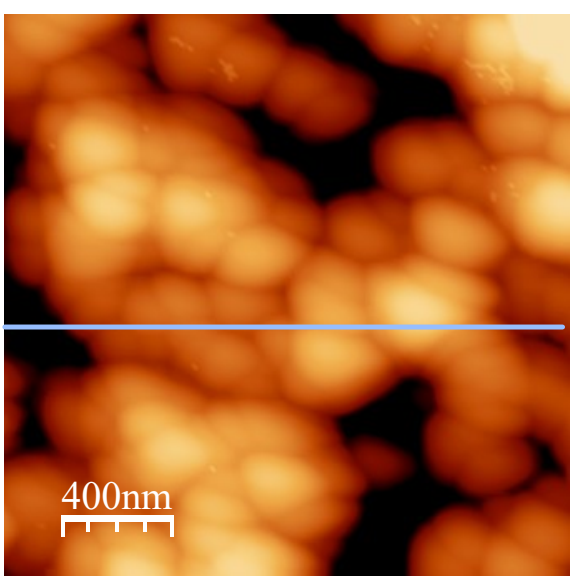

(c)

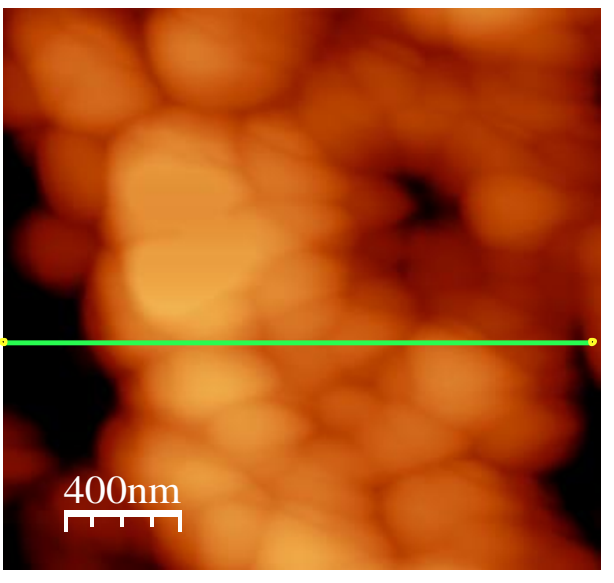

(e)
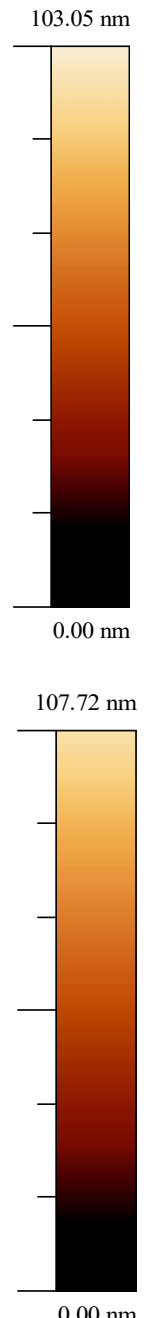

$0.00 \mathrm{~nm}$

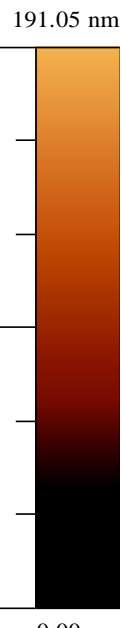

$0.00 \mathrm{~nm}$

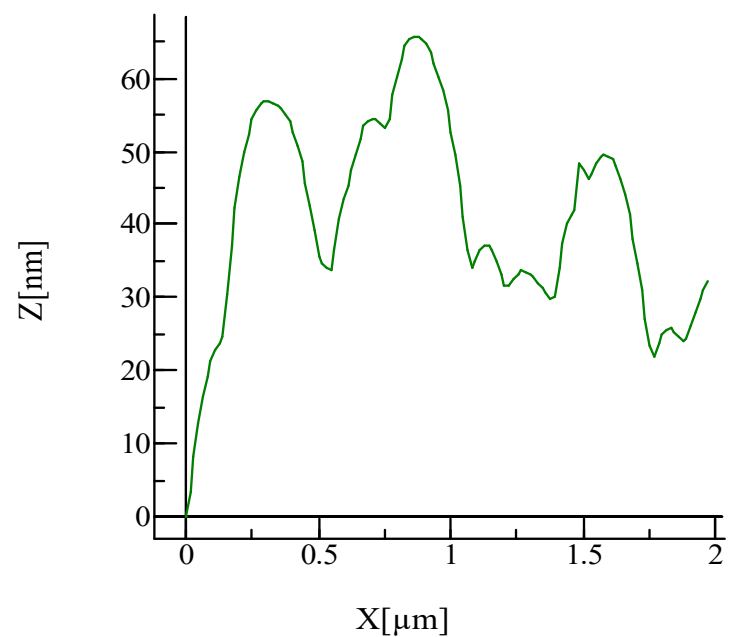

(b)

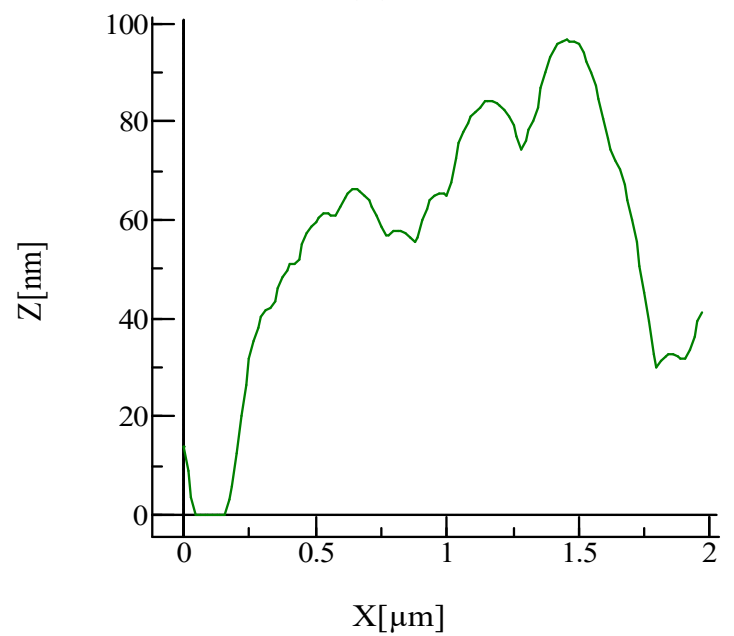

(d)

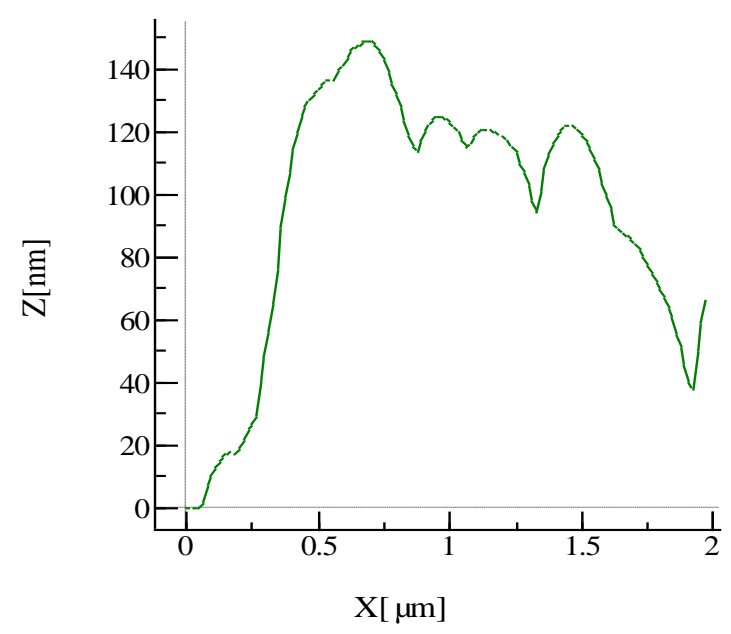

(f)

Figure 8. AFM images of pure and Mg-doped Mn-O oxide: (a,c,e) Surface morphology for pure, 3\% and 5\% Mg-doped Mn-O oxide. $(\mathbf{b}, \mathbf{d}, \mathbf{f})$ surface profiles measured along the horizontal lines shown on the corresponding AFM images.

These AFM observations diverge a little from those obtained in SEM. We suggest this may be due to the fact that the SEM technique takes into account the contribution of the 
microstructures of the subsurface layers, whereas AFM is probing exclusively the extreme surface of the films.

\subsection{Optical Measurements}

The transmittance $(\mathrm{T})$ or absorbance $(\alpha)$ optical properties of the MnO samples were determined by using UV-visible spectrometry in a double beam spectrophotometer. $\mathrm{T}$ and $\alpha$ spectra were recorded in the 200-900 nm range as shown in Figure 9. It appears that the transmittance is less than $50 \%$ for all samples; as a result, the synthesized films are clearly not so transparent: this is attributed to the inhomogeneity of the deposit as shown by the AFM analysis. The transmittance is varying from $30 \%$ to $15 \%$ for pure manganese oxide and to $9 \%$ for the $\mathrm{Mg}$-doped $\mathrm{Mn}-\mathrm{O}$ films; thus, the $\mathrm{Mg}$ doping reduces greatly the samples transparency.

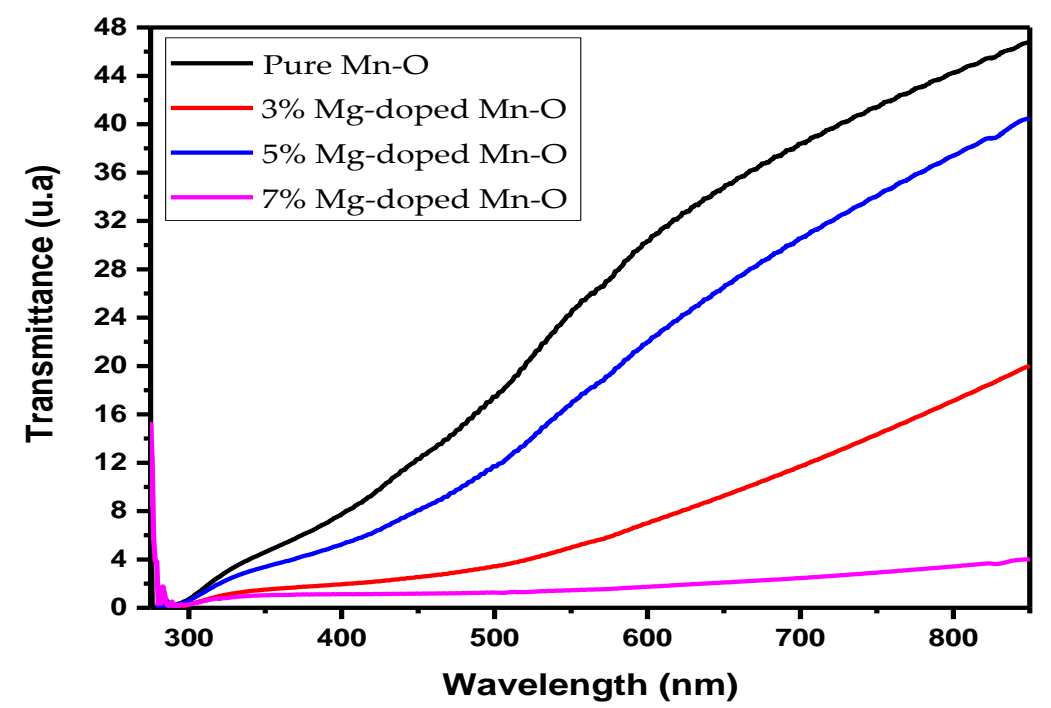

Figure 9. Transmittance spectra of the pure and Mg-doped Mn-O films.

By combining the transmittance and absorption data, the value of the MnO energy gap is calculated from the Tauc's plot [32], using the equation:

$$
(\alpha \mathrm{h} v)^{2}=\mathrm{A}(\mathrm{h} v-\mathrm{Eg})
$$

where $\alpha$ is the absorption yield, hv is the photon energy, $\mathrm{A}$ is a constant and $\mathrm{Eg}$ is the band gap energy.

A typical plot of $(\alpha \mathrm{h} v)^{2}$ versus (hv) is shown in Figure 10. According to Equation (5), the extrapolation on Figure 10 of the linear portion of the curve to $(\alpha \mathrm{h} v)^{2}=0$ gives the Eg band gap values listed in Table 4 . They are found to be in between $1.4-2.5 \mathrm{eV}$, with the band gap decreasing with the increase of Mg-doping. As interpreted in earlier paragraphs, this may be due to the greater ionic radius of $\mathrm{Mg}^{2+}$ ions compared to the $\mathrm{Mn}^{2+}$ ones. The insertion of $\mathrm{Mg}^{2+}$ in the $\mathrm{Mn}^{2+}$ sites creates defects resulting from the distortion in the $\mathrm{MnO}$ lattice. The decrease in band gap with doping can be also linked to the presence of voids formed by the magnesium ions substituting the manganese ones in the host lattice. Similar results have been observed in $\mathrm{Mg}$ and $\mathrm{Ga}$ co-doped $\mathrm{ZnO}$ and in molybdenum-doped indium oxide thin films $[33,34]$. In general, the band gap values obtained in this study for pure and $\mathrm{Mg}$-doped samples are in the range of those reported in the literature [35-38]. 


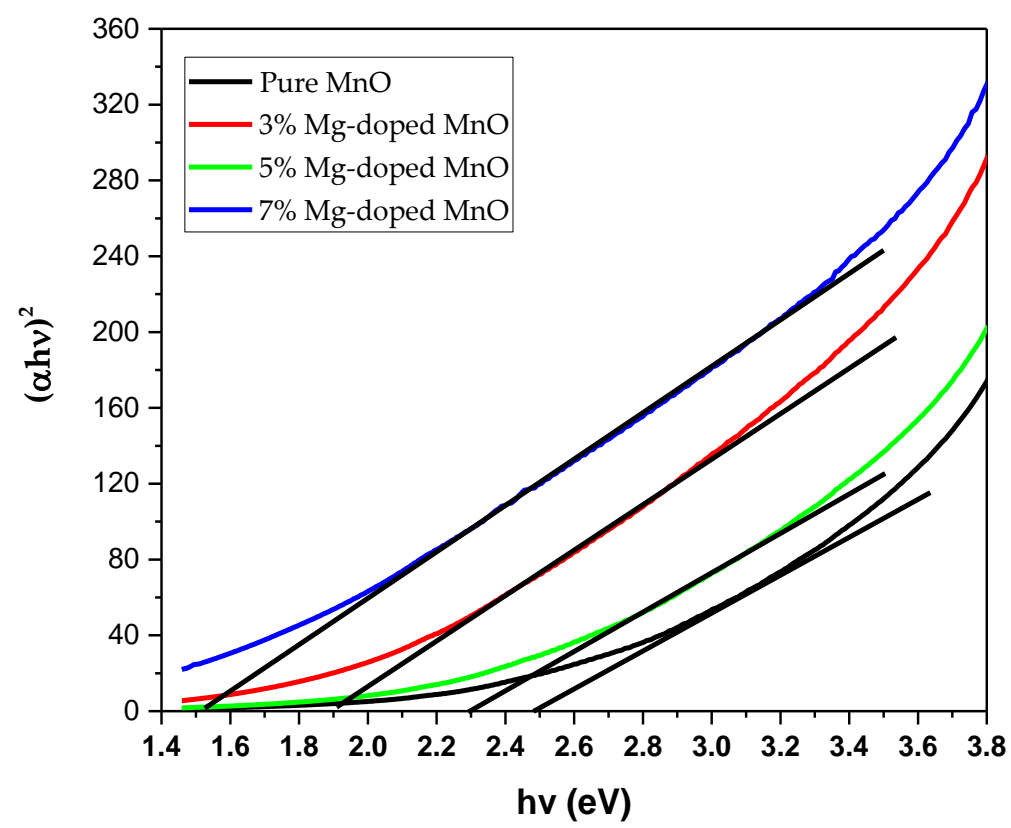

Figure 10. Eg band gap energy extracted from the Tauc's plot for the different deposited films.

Table 4. Effect of Mg-doping on Eg values.

\begin{tabular}{cc}
\hline Sample & Eg (eV) \\
\hline Pure MnO & 2.5 \\
3\% Mg-doped $\mathrm{MnO}$ & $1: 9$ \\
$5 \% \mathrm{Mg}$-doped $\mathrm{MnO}$ & 2.3 \\
$7 \% \mathrm{Mg}$-doped $\mathrm{MnO}$ & 1.5 \\
\hline
\end{tabular}

\section{Conclusions}

This report studied the chemical composition, the structural, morphological and optical properties of $\mathrm{Mn}_{3} \mathrm{O}_{4}$ films deposited on glass substrate heated at $350{ }^{\circ} \mathrm{C}$ by spray pyrolysis. XPS characterization highlighted the chemical composition of $\mathrm{Mn}_{3} \mathrm{O}_{4}$ films. XRD analysis evidenced the $\mathrm{Mn}_{3} \mathrm{O}_{4}$ polycrystalline phase in a tetragonal structure with an intense diffraction plane (211), the preferred growth orientation along this direction. SEM images showed a rough surface for $\mathrm{Mn}_{3} \mathrm{O}_{4}$ films with is improved with the Mg-doping increase. AFM showed textured surface formed by nanograins shaped like an "egg". UVvisible spectroscopy revealed a transmittance yield ranging between $15-30 \%$. This low yield is probably due to the porosity of the surface. The Eg band gap energy determined from Tauc plots $(2.0-3.3 \mathrm{eV})$ are in accordance with those of the literature. The results of this study are going to be used for further characterization of photocatalytical properties for application in industrial waste treatment.

Author Contributions: M.G. proposed, designed the study and wrote the paper; M.A.D. performed the experiments; S.E.N., C.F., and D.T. contributed to the interpretations of the results and paid the invoice of the publication charge; J.-J.P. supervised and commented the final article version; A.B. discussed some results. In general, all authors contributed to the discussion and interpretation of the results. All authors have read and agreed to the published version of the manuscript.

Funding: This research was funded by the "Laboratoire des Sciences de la Matière Condensée (LSMC)" and the "Centre Interdisciplinaire de Nanoscience de Marseille" in the framework of the $\mathrm{PhD}$ thesis of M.A.D.

Institutional Review Board Statement: Not applicable.

Informed Consent Statement: Not applicable. 
Data Availability Statement: Data is contained within the article.

Conflicts of Interest: The authors declare no conflict of interest.

\section{References}

1. Lee, J.D. Concise Inorganic Chemistry, 4th ed.; Chapman-Hall: London, UK, 1991.

2. Rühle, S.; Anderson, A.Y.; Barad, H.-N.; Kupfer, B.; Bouhadana, Y.; Rosh-Hodesh, E.; Zaban, A. All-oxide photovoltaics. J. Phys. Chem. Lett. 2012, 3, 3755-3764. [CrossRef] [PubMed]

3. Jin, B.; Yan, Q.; Dou, Y. Materials for energy storage and conversion based on metal oxides. Recent Patents Mater. Sci. 2012, 5, 199-212. [CrossRef]

4. Reddy, R.N.; Reddy, R.G. Synthesis and electrochemical characterization of amorphous $\mathrm{MnO}_{2}$ electrochemical capacitor electrode material. J. Power Sources 2004, 132, 315-320. [CrossRef]

5. Reddy, R.N.; Reddy, R.G. Electrochemical Capacitor and Hybrid Powder Sources; The Electrochemical Society Proceeding Series; PV 2002-7: Pennington, NJ, USA, 2002.

6. Xu, C.; Miyazaki, K.; Watanable, T. Humidity sensors using manganese oxides. Sens. Actuators B 1998, 46, 87. [CrossRef]

7. Zou, Z.; Ye, J.; Sayama, K.; Arakawa, H. Direct splitting of water under visible light irradiation with an oxide semiconductor photocatalyst. Nat. Cell Biol. 2001, 414, 625-627. [CrossRef] [PubMed]

8. Minami, T. Transparent conducting oxide semiconductors for transparent electrodes. Semicond. Sci. Technol. 2005, 20, S35-S44. [CrossRef]

9. Jung, H.W.; Jeong, Y.U. Electrochemical properties of various transition metal oxides for energy storage. Stud. Surf. Sci. Catal. 2006, 159, 633

10. Suprun, W.; Lutecki, M.; Glaser, R.; Papp, H.J. Catalytic activity of bifunctional transition metal oxide containing phosphated alumina catalysts in the dehydration of glycerol. Mol. Catal. A Chem. 2011, 342-343, 91-100. [CrossRef]

11. Kuznetsov, I.A.; Greenfield, M.J.; Mehta, Y.U.; M-Merchan, W.; Salkar, G.; Saveliev, A.V. Increasing the solar cell power output by coating with transition metal-oxide nanorods. Appl. Energy 2011, 88, 4218-4221. [CrossRef]

12. Burton, B.B.; Fabreguette, F.H.; George, S.M. Atomic layer deposition of MnO using Bis (ethylcyclopentadienyl) manganese and $\mathrm{H}_{2} \mathrm{O}$. Thin Solid Films 2009, 517, 5658-5665. [CrossRef]

13. Cao, L.; Wang, R.; Xu, Z.; Li, J.; Huang, J.; Li, R.; Li, K. Constructing MnOC bonds in $\mathrm{Mn}_{3} \mathrm{O}_{4} /$ Super P composite for superior performance in Liion battery. J. Electroanal. Chem. 2017, 798, 1-8. [CrossRef]

14. Lin, C.C.; Jhan, J.H. Influence of substrate treatment temperatures and bias potential on capacitive manganese-cobalt-zinc oxide thin films deposited by radio frequency sputtering. Electrochim. Acta 2011, 56, 6757-6763. [CrossRef]

15. Guo, L.W.; Ko, H.J.; Makino, H.; Chen, Y.F.; Inaba, K.; Yao, T.J. Epitaxial growth of $\mathrm{Mn}_{3} \mathrm{O}_{4}$ film on $\mathrm{MgO}(0001)$ substrate by plasma-assisted molecular beam epitaxy (MBE). Cryst. Growth 1999, 205, 531-536. [CrossRef]

16. Gorbenko, O.Y.; Graboy, I.E.; Amelichev, V.A.; Bosak, A.A.; Kaul, A.R.; Guttler, B.; Svetchnikov, V.L.; Zandbergen, H.W. The structure and properties of $\mathrm{Mn}_{3} \mathrm{O}_{4}$ thin films grown by MOCVD. Solid State Commun. 2002, 124, 15-20. [CrossRef]

17. Vijayalakshmi, K.; Renitta, A.; Jereil, S.D.; Alagusundaram, K. Highly (101) oriented $\mathrm{MnO}_{2}$ nanofibers synthesized using novel spray pyrolysis technique. J. Mater. Sci. Mater. Electron. 2015, 26, 9782-9788. [CrossRef]

18. Yadav, A.A. Influence of electrode mass-loading on the properties of spray deposited $\mathrm{Mn}_{3} \mathrm{O}_{4}$ thin films for electrochemical supercapacitors. Thin Solid Films 2016, 608, 88-96. [CrossRef]

19. Boulila, S.; Ghamnia, M.; Boukhachem, A.; Ouhaibi, A.; Chakhoum, M.A.; Fauquet, C.; Heresanu, V.; Tonneau, D. Photocatalytical properties of $\mathrm{NiO}$ nanofilms doped with Ba. Phil. Mag. Lett. 2020, 110, 283-293. [CrossRef]

20. Benameur, N.; Chakhoum, M.; Boukhachem, A.; Dahamni, M.; Ghamnia, M.; Hacini, N.; Pireaux, J.-P.; Houssiau, L.; Ziouche, A. Investigation of some physical properties of pure and Co-doped $\mathrm{MoO}_{3}$ synthesized on glass substrates by the spray pyrolysis method. J. Electron Spectrosc. Relat. Phenom. 2019, 234, 71-79. [CrossRef]

21. Li, N.; Tian, Y.; Zhao, J.; Zhang, J.; Zhang, J.; Zuo, W.; Ding, Y. Efficient removal of chromium from water by $\mathrm{Mn}_{3} \mathrm{O}_{4} @ \mathrm{ZnO} \mathrm{Mn}_{3}$ $\mathrm{O}_{4}$ composite under simulated sunlight irradiation: Synergy of photocatalytic reduction and adsorption. Appl. Catal. B Environ. 2017, 214, 126-136. [CrossRef]

22. Ilton, E.S.; Droubay, T.C.; Chaka, A.M.; Kovarik, L.; Varga, T.; Arey, B.W.; Kerisit, S.N. Epitaxial single-crystal thin films of $\mathrm{Mn}_{x} \mathrm{Ti}_{1-x} \mathrm{O}_{2-\delta}$ grown on (rutile) $\mathrm{TiO}_{2}$ substrates with pulsed laser deposition: Experiment and theory. Surf. Sci. 2015, 632, 185-194. [CrossRef]

23. Ilton, E.S.; Post, J.E.; Heaney, P.J.; Ling, F.T.; Kerisit, S.N. XPS determination of Mn oxidation states in Mn (hydr)oxides. Appl. Surf. Sci. 2016, 366, 475-485. [CrossRef]

24. Cerrato, J.M.; Hochella, M.F., Jr.; Knocke, W.R.; Dietrich, A.M.; Cromer, T.F. Use of XPS to identify the oxidation state of Mn in solid surfaces of filtration media oxide samples from drinking water treatment plants. Environ. Sci. Technol. 2010, 44, 5881-5886. [CrossRef]

25. Cerrato, J.M.; Knocke, W.R.; Hochella, M.F., Jr.; Dietrich, A.M.; Jones, A.; Cromer, T.F. Application of XPS and solution chemistry analyses to investigate soluble manganese removal by $\mathrm{MnO}_{x}(\mathrm{~s})$-coated media. Environ. Sci. Technol. 2011, 45, 10068-10074. [CrossRef] [PubMed]

26. Bayram, O.; Guney, H.; Ertargin, M.E.; Igman, E.; Simsek, O. Effect of doping concentration on the structural and optical properties of nanostructured $\mathrm{Cu}$-doped $\mathrm{Mn}_{3} \mathrm{O}_{4}$ films obtained by SILAR technique. Appl. Phys. A 2018, 124, 606. [CrossRef] 
27. Larbi, T.; Ouni, B.; Boukhachem, A.; Boubaker, K.; Amlouk, M. Investigation of structural, optical, electrical and dielectric properties of catalytic sprayed hausmannite thin film. Mater. Res. Bull. 2014, 60, 457-466. [CrossRef]

28. Adhikari, R.; Das, A.K.; Karmakar, D.; Rao, T.V.C.; Ghatak, J. Structure and magnetism of Fe-doped $\mathrm{SnO}_{2}$ nanoparticles. Phys. Rev. B 2008, 78, 024404. [CrossRef]

29. Ouhaibi, A.; Ghamnia, M.; Dahamni, M.A.; Heresanu, V.; Fauquet, C.; Tonneau, D. The effect of strontium doping on structural and morphological properties of $\mathrm{ZnO}$ nanofilms synthesized by ultrasonic spray pyrolysis method. J. Sci. Adv. Mater. Devices 2018, 3, 29-36. [CrossRef]

30. Adav, A.; Jadhav, S.; Chougule, D.; Patil, P.; Chavan, U.; Kolekar, Y. Spray deposited Hausmannite $\mathrm{Mn}_{3} \mathrm{O}_{4}$ thin films using aqueous/organic solvent mixture for supercapacitor applications. Electrochim. Acta 2016, 206, 134-142. [CrossRef]

31. Raj, A.M.E.; Victoria, S.G.; Jothy, V.B.; Ravidhas, C.; Wollschläger, J.; Suendorf, M.; Neumann, M.; Jayachandran, M.; Sanjeeviraja, C. XRD and XPS characterization of mixed valence $\mathrm{Mn}_{3} \mathrm{O}_{4}$ hausmannite thin films prepared by chemical spray pyrolysis technique. Appl. Surf. Sci. 2010, 256, 2920-2926.

32. Borchert, H.; Shevchenko, E.V.; Robert, A.; Mekis, I.; Kornowski, A.; Grubel, G.; Weller, H. Determination of nanocrystalsizes: Comparison of TEM; SAXS and XRD studies of highly monodisperse CoPt 3 particles. Langmur 2005, 21, 1931-1936. [CrossRef]

33. Tauc, J.; Menth, A. States in the gap. J. Non-Cryst. Solids 1972, 8-10, 569-585. [CrossRef]

34. Parthiban, S.; Gokulakrishnan, V.; Ramamurthi, K.; Elangovan, E.; Martins, R.; Fortunato, E.; Ganesan, R. High nearinfrared transparent molybdenum-doped indium oxide thin films for nanocrystalline silicon solar cell applications. Solar Energy Mater. Solar Cells 2009, 93, 92-97. [CrossRef]

35. Sheikhshoaie, I.; Ramezanpour, S.; Khatamian, M. Synthesis and characterization of thallium doped $\mathrm{Mn}_{3} \mathrm{O}_{4}$ as superior sunlight photocatalysts. J. Mol. Liq. 2017, 238, 248-253. [CrossRef]

36. Amara, M.; Larbi, T.; Labidi, A.; Karyaoui, M.; Ouni, B.; Amlouk, M. Microstructural, optical and ethanol sensing properties of sprayed Li-doped $\mathrm{Mn}_{3} \mathrm{O}_{4}$ thin films. Mater. Res. Bull. 2016, 75, 217-223. [CrossRef]

37. Zhou, W.; Zhanga, L.; Ouyang, C.; Wu, J.; Huang, Z.; Xu, X.-F. Micro structural, electrical and optical properties of highly (2 2 0) oriented spinel Mn-Co-Ni-O film grown by radio frequency magnetron sputtering. Appl. Surf. Sci. 2014, 311, 443-447. [CrossRef]

38. Kovendhan, M.; Joseph, D.P.; Manimuthu, P.; Sendil Kumar, A.; Karthick, S.N.; Sambasivam, S.; Vijayarangamuthu, K.; Kim, H.J.; Choi, B.C.; Asokan, K.; et al. Prototype electrochromic device and dye sensitized solar cell using spray deposited undoped and 'Li' doped $\mathrm{V}_{2} \mathrm{O}_{5}$ thin film electrodes. Curr. Appl. Phys. 2015, 15, 622-631. [CrossRef] 